\title{
Paired terraces of the Seuti Khola, Dharan, eastern Nepal
}

\author{
Matrika Prasad Koirala1,2,3*, Sunil Kumar Dwivedi1,2,3, Prakash Dhakal33, Ghanashyam Neupane ${ }^{3}$, \\ Yadav Prasad Dhakal ${ }^{3}$, Suresh Prasad Khanal ${ }^{3}$, Niraj Kumar Regmi ${ }^{3}$, Gobinda Ojha ${ }^{3}$, Suchita \\ Shrestha ${ }^{3}$ and Ranjan Kumar Dahal ${ }^{1,3}$ \\ 1 Department of Geology, Tri-Chandara Campus, Tribhuvan University, Kathmandu, NEPAL \\ 2 Simulation Tectonics Laboratory, Faculty of Sciences, University of the Ryukyus, Nishihara, Okiwana, 901-0213, JAPAN \\ 3 Central Department of Geology Tribhuvan University, Kathmandu, NEPAL \\ * For correspondence, email: matrikakoirala@hotmail.com
}

Terraces are the geomorphic units once occupied by the rivers. When a river cuts down into its flood plain, the former alluvial surface is no longer flooded and is left as a more or less flat terrace above the new level of the river. If the downcutting resumes, a second pair of terrace may then be left on the valley side. Terrace mapping on the riverside is important in evaluating the environmental impact of the river to the adjacent area. The suitability of area to a particular landuse, and the possible action of river on the adjacent area of the river can also be understood from the terrace mapping. About $4 \mathrm{~km}$ stretches of the Seuti Khola, east of the Dharan Bazar has been mapped to illustrate the terrace patterns associated to this stream. The Seuti Khola is a hilly stream, characterized by low discharge during dry season, but tremendously high flow during rainy time. The river valley is wide $(>150 \mathrm{~m})$ consisting of boulder-cobble beds. The stream valley has gradient of about $2^{\circ}$. Within the mapped area the river channels drops from $480 \mathrm{~m}$ elevation at upper reaches to $340 \mathrm{~m}$ elevation at the lower reaches. This provides high energy to the river during high discharge level that is capable of transporting boulder-sized clasts.
Four levels of terraces on each side has been identified and mapped on either side. The terraces are of paired type, thus can be individually recognized on either side. These terraces are well developed, and can easily be recognized as being successive steplike geomorphic units. Lower Terrace $\left(\mathrm{T}_{1}\right)$ is about 5 to $10 \mathrm{~m}$ above the present river channels. This terrace is distributed within elevation range of $350-400 \mathrm{~m}$. The Lower Middle Terrace $\left(\mathrm{T}_{2}\right)$ is distributed within $370-440 \mathrm{~m}$ level. Upper Middle Terrace $\left(\mathrm{T}_{3}\right)$ is situated between $390-460 \mathrm{~m}$ levels. Similarly, the Upper Terrace $\left(\mathrm{T}_{4}\right)$ is identified above $410-550 \mathrm{~m}$ level.

The terraces of the Seuti Khola might be the evidence of the neo-tectonic activity in the Himalayan realm. The terraces along this stream are resulted due to the recent upliftment of the area. The terrace forming material is characterized by the northtilting loose boulder-beds exposed on the steep riverbank scarps. This may be due to the rapid upward and southward movement associated with the Himalayan Frontal Thrust (HFT) that carries the Sub-Himalaya as hanging wall, onto the footwall of the Terai sediments. The continuous upliftment provides the extra elevation to be undercut by the stream. 